\title{
Drought Risk to the Agriculture Sector
}

\author{
By David Rodziewicz and Jacob Dice
}

fter experiencing severe flooding in 2019 , areas of the west-
ern United States and Great Plains are once again starting to
experience drought. The average share of the continental Unit-
ed States experiencing drought rose from a little less than 24 percent in
2019 to over 40 percent in 2020 . Drought is a perennial and long-term
risk that can negatively affect the farm economy through lower yields,
loss of crops, reduced farm revenues, and lower sales for farm suppli-
ers. Recent drought episodes have kept these economic costs front of
mind for farmers, agribusinesses, and agricultural lenders. Losses from
the 2012 Midwest and $2011-17$ California droughts still loom large,
with national disaster costs near $\$ 35$ billion in 2012 for the Midwest
drought and $\$ 4$ billion in 2014 for the California drought.
As risks from climate change- - such as elevated global temperatures
and water depletion-mount, understanding how drought will affect
farmers across the country has become even more important. Drought

David Rodziewicz is a senior economics specialist at the Federal Reserve Bank of Kansas City. Jacob Dice is a research associate at the bank. The authors wish to thank Ashley Hungerford and Thomas Worth from the U.S. Department of Agriculture (USDA) and Jennifer Bell from the Office of Management and Budget (OMB) for their guidance on USDA crop insurance data. The authors also thank Michael Brewer, Adam Smith, and Eugene Wahl at the National Oceanic and Atmospheric Administration (NOAA) for their guidance on drought risk and U.S. Drought Monitor data. This article is on the bank's website at www.KansasCityFed.org 
risk can vary by region, crop type, and production method, and may disproportionately affect some farmers more than others. Although many farmers have crop insurance to protect against losses, insurance does not cover all of their crops' value. Thus, even insured farmers face losses from drought. These losses can weaken farm finances, resulting in financial strain that may spill over into the broader agricultural economy.

In this article, we analyze the relationship between county-level drought exposure and direct farmer losses (specifically, crop insurance deductibles) from 2000 to 2019 . We find that farmer losses from drought vary by crop type: although losses rise steadily along with drought intensity for corn and wheat, losses spike noticeably in extreme drought for soybeans. We also find that these losses represent an economically relevant share of crop production values: farmer losses from extreme drought can reach 20 percent of production value for corn and wheat and 35 percent for soybeans.

Section I provides an overview of U.S. drought, its connection to climate change, and the risks to the U.S. agriculture sector. Section II introduces data and statistical methods used to link drought, agricultural production areas, and farmer losses from drought. Section III shows how farmer losses rise with drought intensity and discusses differences across crop types.

\section{Drought, Climate, and U.S. Agriculture}

Although the U.S. agricultural sector is vulnerable to a myriad of natural hazards - excessive wind, flooding, tornadoes - drought represents an especially severe challenge. First, drought is a chronic condition that affects farms much longer than acute hazards such as storms or floods. The persistence of drought throughout the year may not only lower crop yields, but may also deplete surface and ground water supplies and lead to an increased incidence of wildfires (Challinor and others 2014; Donovan, Wonkka, and Twidwell 2017; Otkin and others 2018). Second, drought's close links to climate mean it is likely to present a growing threat in the future as risks from climate change mount. A combination of rising growing season temperatures, increased drought incidence and severity, and amplified climate and drought variability is likely to depress yields and increase stress for the agriculture sector in the coming decades (Cook and others 2019; Gowda and others 2018; 
Kukal and Irmak 2018; Schlenker 2020). Understanding these challenges — as well as the associated economic costs—can help farmers address increasing drought risk and help lenders better assess that risk for their agricultural borrowers.

\section{U.S. drought exposure and agriculture}

One common way to measure drought in the United States is through the U.S. Drought Monitor, which provides maps of drought intensity and duration. The Drought Monitor uses a series of climate and weather variables to create weekly estimates of drought severity across the United States (U.S. Drought Monitor 2020; Svoboda and others 2002). Drought categories range from "abnormally dry" (D0) to "exceptional drought" (D4). ${ }^{1}$

Chart 1 shows total continental U.S. land area in drought by intensity going back to 2000 . Drought episodes have varied in intensity over the last 20 years. In 2012, for example, the United States witnessed a period of relatively extreme drought, with roughly 67 percent of land area on average in drought and roughly 14 percent of land area in the most extreme drought categories (D3-D4). By comparison, in 2019, the United States witnessed a period of relatively subdued drought, with less than 24 percent of land area on average in drought and less than 1 percent of land area in the most extreme drought categories.

Although aggregate drought exposure estimates are useful in illustrating the scope of the problem, these broader measures can mask the fortunes of local areas at certain times. Drought exposure varies across the country, affecting both local and regional agricultural areas. The Drought Monitor images in Map 1 illustrate two of the more extreme regional drought periods within the United States. Panel A shows the U.S. drought map during July 2012, the height of the 2011-12 Midwest drought. Most of the country was in drought at the time, with large areas of the Midwest in the most extreme drought categories (D3D4). This drought episode resulted in a loss of more than one-quarter of U.S. corn production by volume, nearly $\$ 22$ billion in crop insurance claims payments, and national disaster costs around $\$ 35$ billion (Rippey 2015; NOAA NCEI 2020). In contrast, Panel B shows the drought map during July 2014, the peak of the 2011-19 California drought, which was one of the longest in U.S. history (Williams 2020). 


\section{Chart 1}

U.S. Continental Land Area in Drought

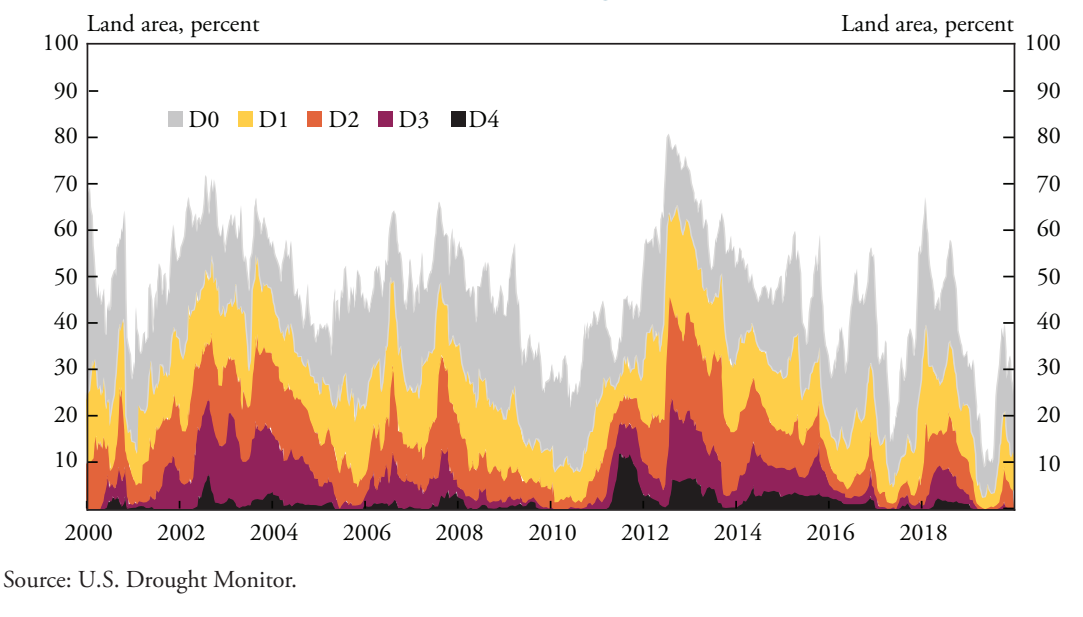

In 2014 alone, California had on average nearly 100 percent of its total land area in drought and 36 percent of its land area in exceptional drought (D4). As a result, 2014 crop insurance claims payments for California exceeded $\$ 305$ million, and national disaster costs for the drought that year totaled roughly $\$ 4$ billion (USDM 2020; NOAA NCEI 2020). ${ }^{2}$

Just as drought varies across the country, the effects of drought can vary by crop or type of production. Farmers planting row crops such as corn, wheat, and soybeans are largely affected by drought through diminished yields and lower production (Kuwayama and others 2018). However, some crops are more drought tolerant than others. Wheat, for example, is typically more drought tolerant than corn or soybeans. Moreover, some crops may respond differently to drought of different intensities: soybeans, for example, are known to face large production losses during severe drought episodes (Troy, Kipgen, and Pal 2015). Although other factors such as irrigation availability or style of production may contribute to drought losses, we focus our main analysis on how farmer losses from drought differ across types of crop production.

\section{Drought and crop insurance}

Although drought presents a substantial risk to the U.S. agriculture sector, one mitigating factor is federal crop insurance, which is 
Map 1

U.S. Drought Maps

Panel A: July 2012

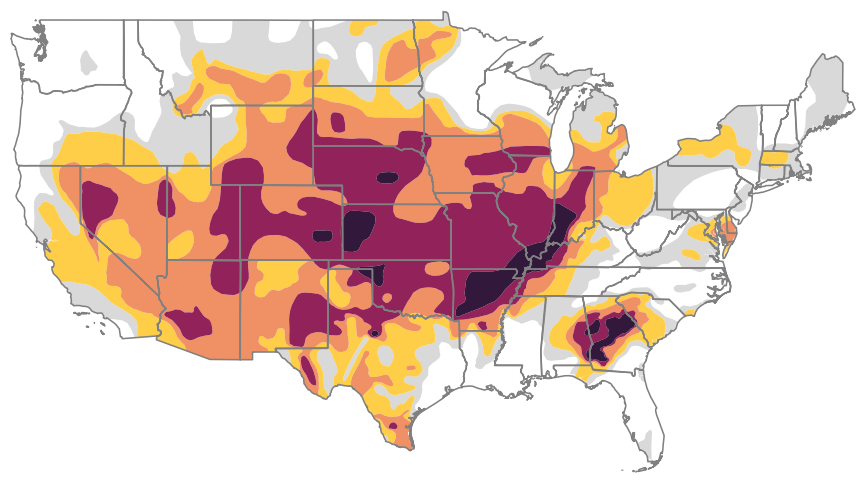

Panel B: July 2014

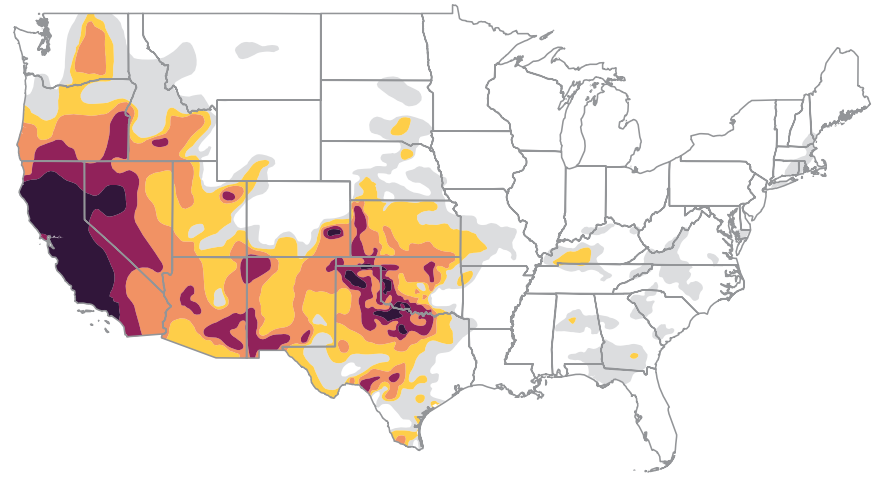

Drought intensity

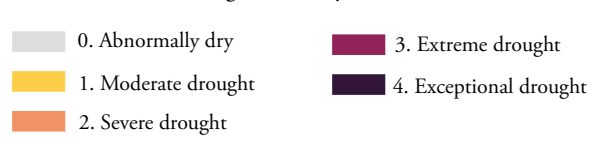

Source: U.S. Drought Monitor.

available for most major commodity crops such as corn, wheat, and soybeans. Roughly 89 percent of major U.S. crop acres are covered by federal crop insurance for a range of natural hazards such as drought (FCA 2017). Encouraging this wide coverage is the fact that federal crop insurance programs are highly subsidized, with the U.S. government paying a majority of insurance premiums (CRS 2018). However, crop insurance does not cover 100 percent of farmer losses. Instead, farmers 


\section{Chart 2}

\section{U.S. Crop Insurance Payments by Category}

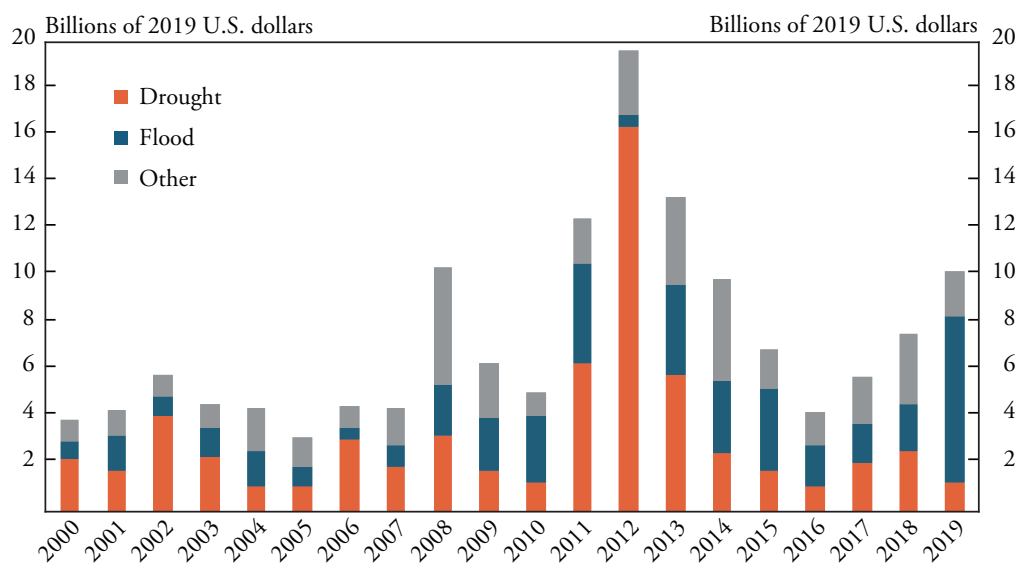

Source: USDA.

file claims on insured losses and receive indemnity payments equal to the losses that exceed their policy deductible. For example, a farmer might elect to purchase insurance that covers up to 75 percent of the value of their crops, making their policy deductible 25 percent. In the event of a severe drought that destroyed 25 percent of the crop value, the farmer would receive no indemnity payment, as the loss did not exceed their deductible. If the drought instead destroyed 60 percent of the crop value, the farmer would receive an indemnity equal to only 35 percent of the crop value $(60-25=35)$. Thus, while crop insurance can mitigate the severity of farmer losses, it does not eradicate loss. It is this portion of farmer losses left over after insurance payouts that we use in our subsequent analysis. See the Box for an overview of federal crop insurance and relevant terminology.

Crop insurance payments nevertheless cover a meaningful share of the value of crop production, and drought is one of the leading reasons farmers file insurance claims. Chart 2 shows crop insurance claims payments (indemnities) by claim type over the last 20 years for the entire United States. Crop insurance indemnities averaged roughly 4.2 percent of total crop production value over the last decade, and drought-related insurance indemnities averaged 1.9 percent of total crop production value. On average, 42 percent of total crop insurance claim payments over the last 20 years were drought-related; in extreme drought years, 


\section{Box}

\section{Federal Crop Insurance Overview}

Federal crop insurance provides protection against natural hazards such as flood and drought as well as declines in commodity prices. A majority of crop insurance policies (84 percent) are categorized as individual revenue protection, which protects a farmer's estimated production value (revenue) from production losses (CRS 2018). The value of a farmer's insured crop is based on historical commodity exchange prices and the historical production from that farmer's land. Farmers choose the average yield they wish to insure (coverage level), which typically ranges from 50 to 75 percent but can be as high as 85 percent in some locations (USDA RMA 2020). Coverage levels are broken down into two broad categories: catastrophic (CAT) and buy-up. CAT coverage, which is less common, is paid out at 55 cents for every dollar of losses exceeding 50 percent of the crop value. Most farmers choose buy-up coverage, paying a higher premium for a higher coverage level, and are paid out dollar-for-dollar for all losses exceeding their chosen coverage level.

The figure below illustrates a stylized buy-up crop insurance policy. The dotted line shows the farmer's elected coverage level-in this example, 75 percent. If the farmer sees a 60 percent loss from a natural hazard, the farmer would be paid an indemnity of 35 percent of the insured crop value (green area). That farmer would still have 40 percent of their crop's value to sell or market (gray area). Despite filing the crop insurance claim, the farmer would still absorb a loss (deductible) equal to 25 percent of the crop's estimated value (blue area). It is this deductible that we use to measure direct economic losses for farmers.

\section{Crop Insurance Policy}

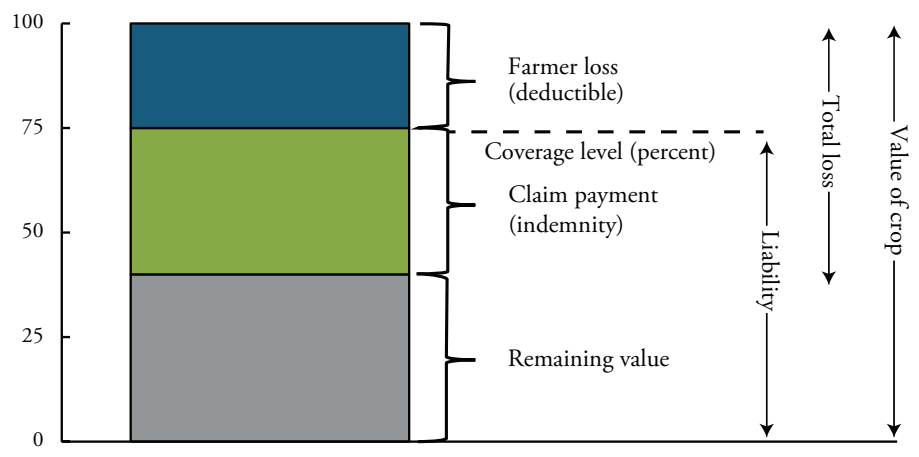


this figure has reached as high as 83 percent. $^{3}$ As these data demonstrate, drought is a substantial risk for the agriculture sector, and crop insurance can help mitigate some of those risks for U.S. farmers.

\section{Mapping Drought to Farmer Losses}

Given the importance of crop insurance for drought-related losses, especially for commodity crops, we use farmer crop insurance deductibles as our measure of farmer losses and focus specifically on losses to corn, wheat, and soybeans. Focusing on commodity crops allows us to gain broad geographic coverage across 47 continental U.S. states while excluding specialty crops such as fruits and tree nuts that may have a strikingly different production process or response to drought. ${ }^{4}$ Furthermore, corn, soybeans, and wheat in total make up over half of U.S. crop production by value and have some of the highest crop insurance market penetration: 89 percent of corn acres, 90 percent of soybean acres, and 85 percent of wheat acres are insured. By focusing on these crops, we can analyze a majority of farmer losses for these crops across most of the United States in the last 20 years (FCA 2017). ${ }^{5}$

In our analysis, we first identify which agricultural production areas are exposed to drought at the county level using a series of geospatial data sets. We then use a simple statistical method to link county-level drought exposures to farmer losses in those counties.

\section{Mapping crop-specific drought exposure}

To create county-level drought exposure measures, we map drought exposure to commodity-specific agricultural production areas across the United States over the last 20 years. Specifically, we take weekly drought data from the U.S. Drought Monitor on agricultural land area in drought and match that information to crop-specific agriculture production areas using the U.S. Department of Agriculture's Cropscape Cropland Data Layer. After matching the weekly drought data to cropspecific production areas, we then create average annual drought exposures at the county crop level (that is, average acres of corn, soybeans, and wheat in each county exposed to D0-D4 drought).

Map 2 shows our county-level drought exposure measures over two three-year periods: $2008-10$, a period of relatively low drought in the United States, and 2011-13, a period of relatively intense drought. 


\section{Map 2}

Average Drought Exposure by County (Corn, Wheat, and Soybeans)

\section{Panel A: 2008-10}
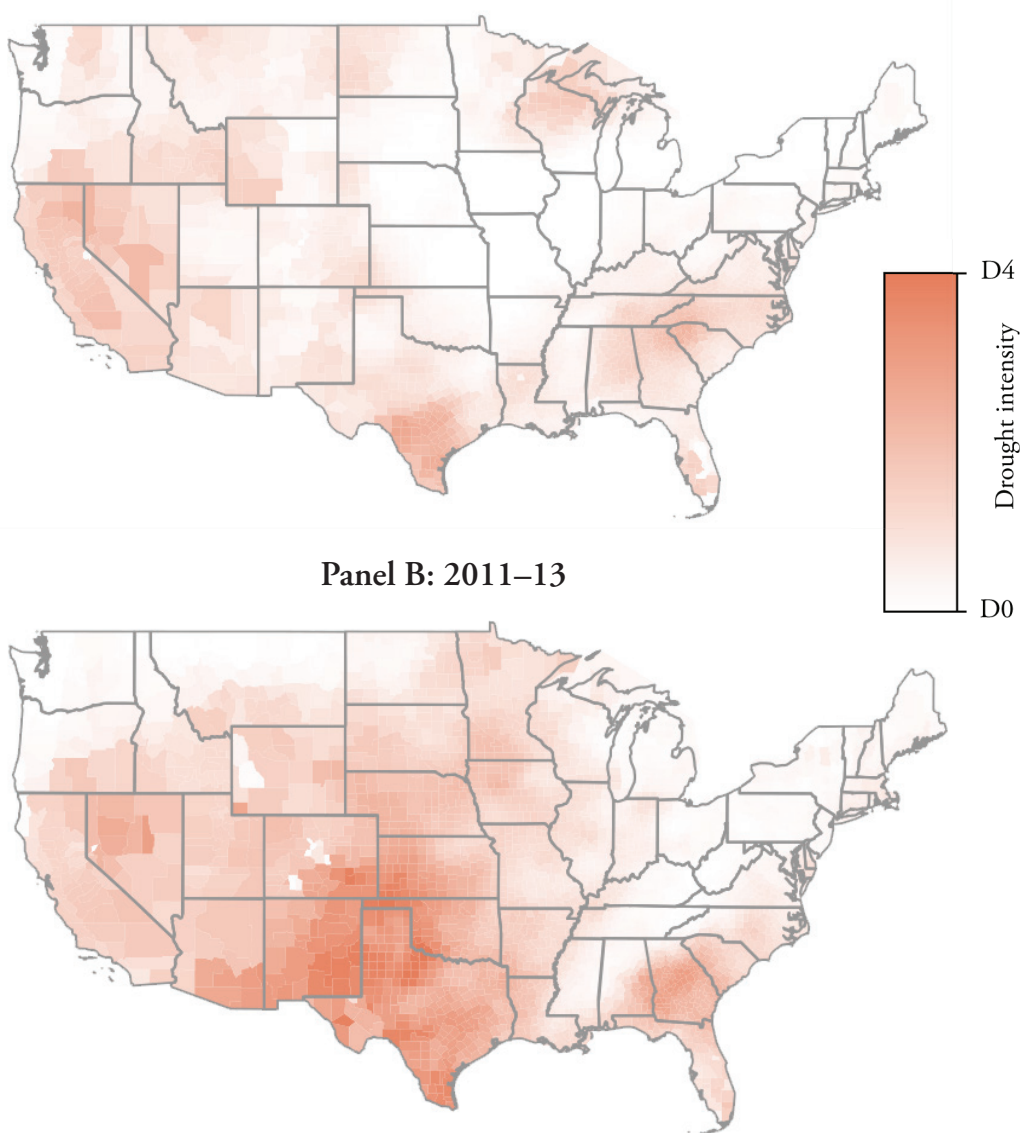

Sources: U.S. Drought Monitor, USDA, and U.S. Census Bureau.

Panel A shows that in the 2008-10 period, average drought intensity was relatively low for the three major commodity crops, with drought occurring mostly in the southern and eastern portion of the country. Panel B shows that in the 2011-13 period, average drought intensity was much higher, with drought occurring mostly in the central and western portion of the United States. 


\section{Measuring and mapping farmer losses from drought}

To measure farmer losses from drought, we aggregate farmer deductibles from drought-related crop insurance claims to the county level. Most prior research uses yields or farm incomes to estimate agricultural losses from drought (Kuwayama and others 2018). Although these are reasonable measures of economic loss, they are imperfect in many ways. Farmers generally manage their operations to maximize profit, not necessarily yield-for example, if commodity prices are especially low, a farmer may choose to let a portion of their fields lie fallow rather than spend time and resources planting. Thus, yields may not fully capture drought's economic effects on farmers. Farm income, on the other hand, can be affected by multiple factors, such as subsidies and changes in operations, making it an unreliable measure of the direct economic effect of drought. Crop insurance data allow us to measure direct drought-related losses at the county crop level for a given year.

We use the USDA's Crop Insurance Cause of Loss and Summary of Business Data to estimate farmer losses for all drought-related crop insurance claims for corn, wheat, and soybeans from 2000 to $2019 .^{6}$ See Appendix A for details on how we measure direct economic losses using these crop insurance data. Panels A and B of Map 3 show heat maps of drought-related losses as a share of county-level crop production values for the 2008-10 and 2011-13 periods. Not surprisingly, drought-related losses are broader-based and more intense during the 2011-13 period than the 2008-10 period. Comparing Map 3 with Map 2 shows that the counties with the greatest economic losses are largely those with the greatest drought intensity. The close relationship at the country crop level between drought exposures and crop insurance deductibles suggests deductibles are a useful measure of direct economic losses from drought.

\section{Linking drought and farmer losses for individual crops}

Although Maps 2 and 3 provide insight into overall farmer losses from drought, they may mask differences in losses across crop types. For example, wheat is typically considered to be more drought tolerant than corn or soybeans, potentially translating to smaller economic losses than those for the other two crops. We use a simple statistical model to estimate the average relationship between agricultural drought exposure 


\section{Map 3}

Average Drought Losses by County as a Share of Production Value (Corn, Wheat, and Soybeans)

Panel A: 2008-10
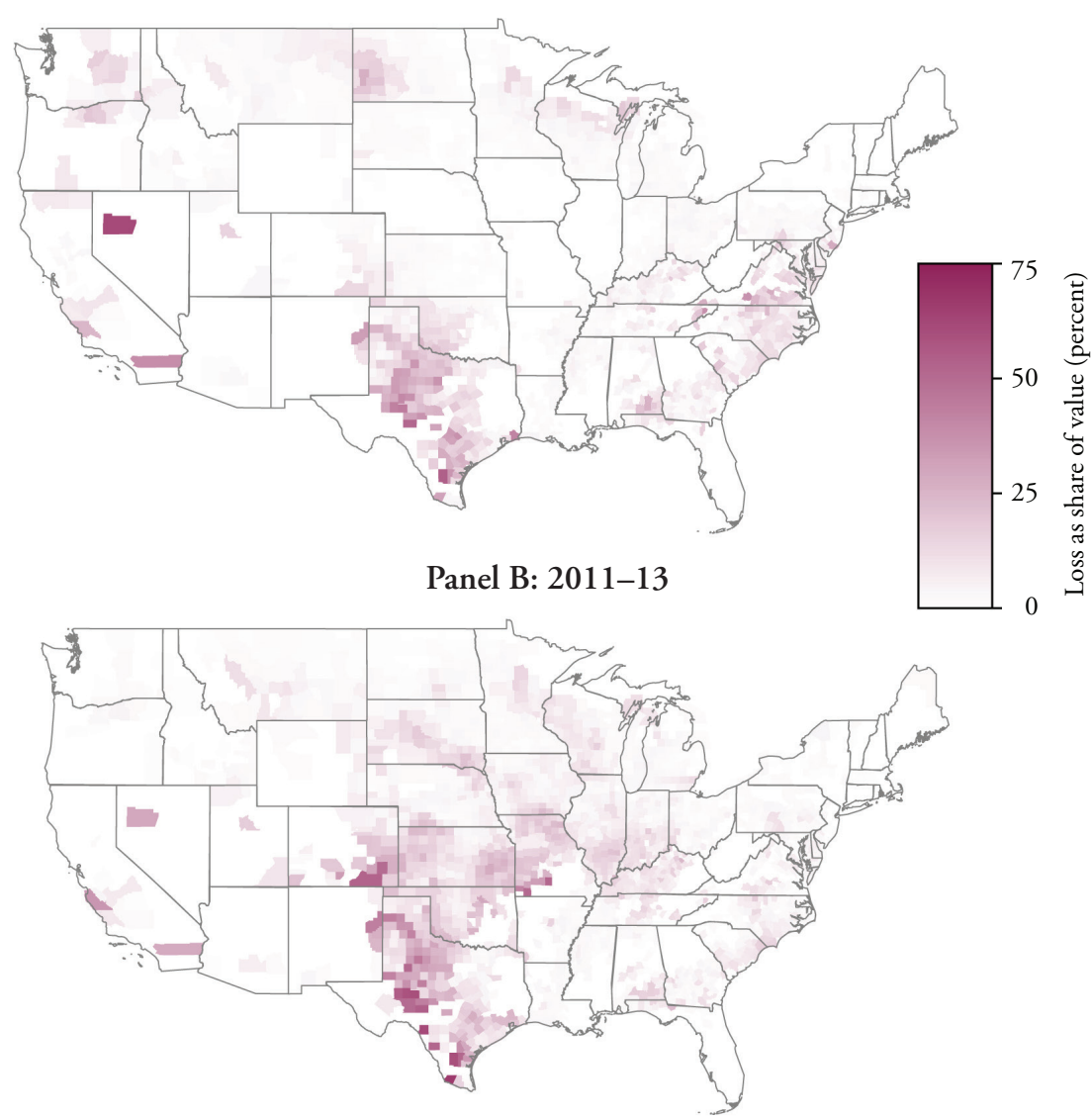

Sources: USDA and U.S. Census Bureau.

and farmer losses (deductibles) for individual crops—corn, soybeans, and wheat-from 2000 to 2019. Our analysis follows a similar statistical framework as Kuwayama and others (2018), who link drought to lower crop yields. We implement an ordinary least squares (fixed effects panel regression) to estimate the relationship between the average number of acres (by crop type) exposed to different drought levels (D0-D4) throughout the year and the dollar value of losses. Using the average annual drought exposures by drought category allows us to capture 
the losses associated with drought intensity as well as duration, both of which matter when assessing direct economic losses from drought. Our final sample covers 2,203 counties and comprises 102,146 unique (county, crop, year) observations, 64,289 of which have a drought crop insurance claim. See Appendix B for details of our statistical model and robustness checks.

\section{Farmer Losses from Drought by Crop Type}

Unsurprisingly, we find a strong positive relationship between drought and direct drought-related farmer losses (deductibles) across all three crops analyzed (corn, wheat, and soybeans). Chart 3 shows the relationship between drought severity and the dollar value of losses per acre, adjusted for inflation using the 2019 Consumer Price Index. The upward-sloping lines show that farmer losses rise along with drought intensity across all three crop types.

However, Chart 3 also shows that the magnitude of losses differs by crop type. For corn, farmer losses range from $\$ 25.32$ per acre in low-severity (D0) drought to $\$ 118.80$ per acre in extreme (D4) drought. For soybeans, farmer losses are lower in D0 drought ( $\$ 10.26$ per acre) but much higher in D4 drought (\$153.40). And for wheat, farmer losses are lowest across drought intensities, ranging from $\$ 6.64$ per acre (D0) to $\$ 44.42$ per acre (D4). The lower losses for wheat can partially be attributed to its lower production value per acre, which averages $\$ 214$ per acre compared with $\$ 599$ per acre for corn and $\$ 441$ per acre for soybeans (USDA ERS 2019).

To account for these differences in production value, Chart 4 shows the same results from Chart 3 as a share of each crop's average production value from 2000 to 2019. ${ }^{7}$ Across all crop types and drought categories, estimates of farmer losses are economically relevant compared with their average production value, with loss shares ranging from less than 5 percent for all three crops in D0 drought to roughly 20 percent for corn and wheat and nearly 35 percent for soybeans in D4 drought.

Chart 4 shows that the trajectory of losses also varies by crop type and drought intensity. Losses for corn and wheat rise relatively slowly and steadily as drought intensity increases from D0 to D4. For both crops, the largest jump in farmer losses per acre occurs between D2 and 


\section{Chart 3}

\section{Loss Per Acre by Drought Category}

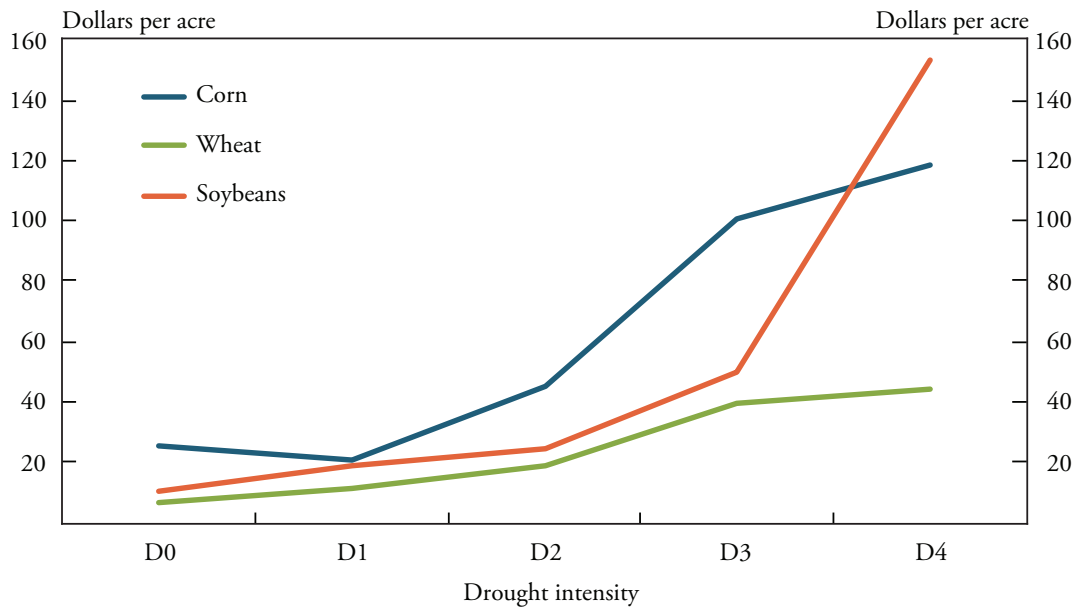

Sources: USDA, U.S. Drought Monitor, and authors' calculations.

\section{Chart 4}

Loss Share by Drought Category

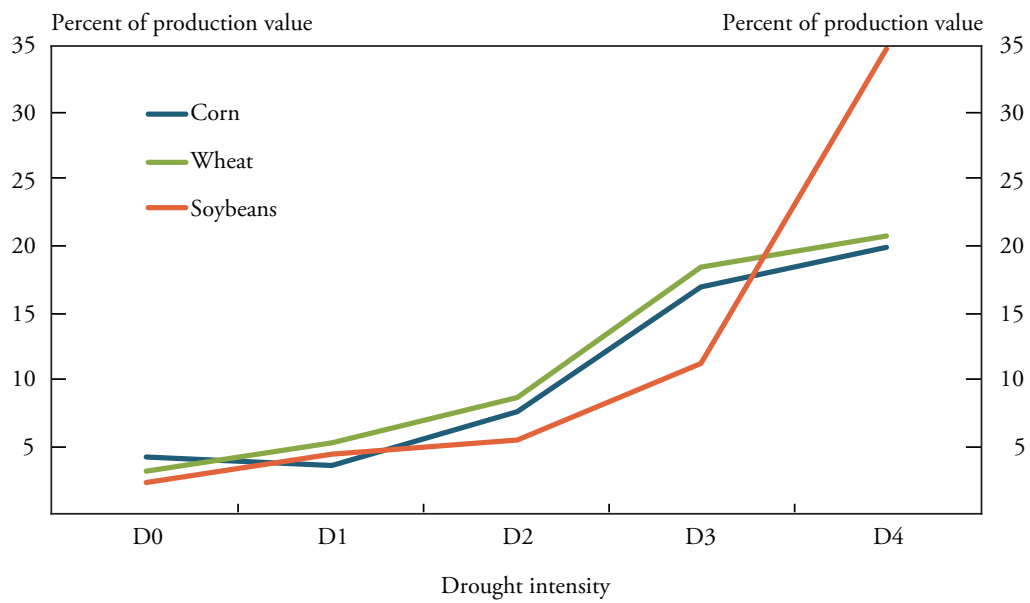

Note: Loss share is based on real 2019 dollar values of production divided by acres of production averaged across the 2000-19 sample period.

Sources: USDA and Bureau of Labor Statistics. 
D3 drought. For corn, losses rise from roughly 8 percent of production value in D2 drought to nearly 17 percent of value in D3 drought. For wheat, losses rise from nearly 9 percent in D2 drought to just over 18 percent in D3 drought. Although soybeans also see a jump in losses between D2 and D3 drought, the largest spike is between D3 and D4 drought. Specifically, losses per soybean acre rise from a little over 11 percent of production value to nearly 35 percent of value. ${ }^{8}$

To provide additional insight into how these losses might affect a given farmer, Chart 5 shows estimated farmer losses (deductibles), indemnities, and remaining crop values for a typical corn, wheat, and soybean farm (similar to the crop insurance policy figure in the Box). $?$ Panel A shows that an average corn farmer with 1,000 acres in severe drought (D2) might expect losses (deductibles) around $\$ 45,000$, or approximately 8 percent of the expected production value for their land. If the corn acres were to move into extreme drought (D3), the farmer's expected losses would be closer to $\$ 101,000$, or roughly 17 percent of production value. Panel $B$ shows that an average wheat farmer with 2,500 acres in severe drought (D2) might expect losses of $\$ 46,000$, or roughly 9 percent of production value; moving into extreme drought (D3) would increase losses to around $\$ 99,000$ or roughly 18 percent of value. Lastly, Panel C shows that an average soybean farmer with 675 acres in extreme drought (D3) might expect losses around $\$ 34,000$ or roughly 11 percent of value; moving into exceptional drought (D4) would increase expected losses to nearly $\$ 104,000$ or about 35 percent of value. As these representative examples demonstrate, even with crop insurance, the losses (deductibles) farmers face from drought can be a meaningful share of their farm's production. ${ }^{10}$

Although our analysis focuses on direct losses to farmers, our results also have implications for risk to crop insurance programs under a changing climate. The green area in Chart 5 shows the estimated indemnity payments from crop insurers to farmers by drought category. In more extreme drought categories, indemnities rise more drastically than farmer losses. For example, corn indemnity payments rise from roughly 6 percent of crop production value in D0 drought to about 35 percent in $\mathrm{D} 4$ drought (Panel A). Wheat indemnities face a similar trajectory, rising from around 4 percent of production value in D0 drought to roughly 24 percent in D4 drought (Panel B). Soybean 


\section{Chart 5}

Loss Share by Drought Category
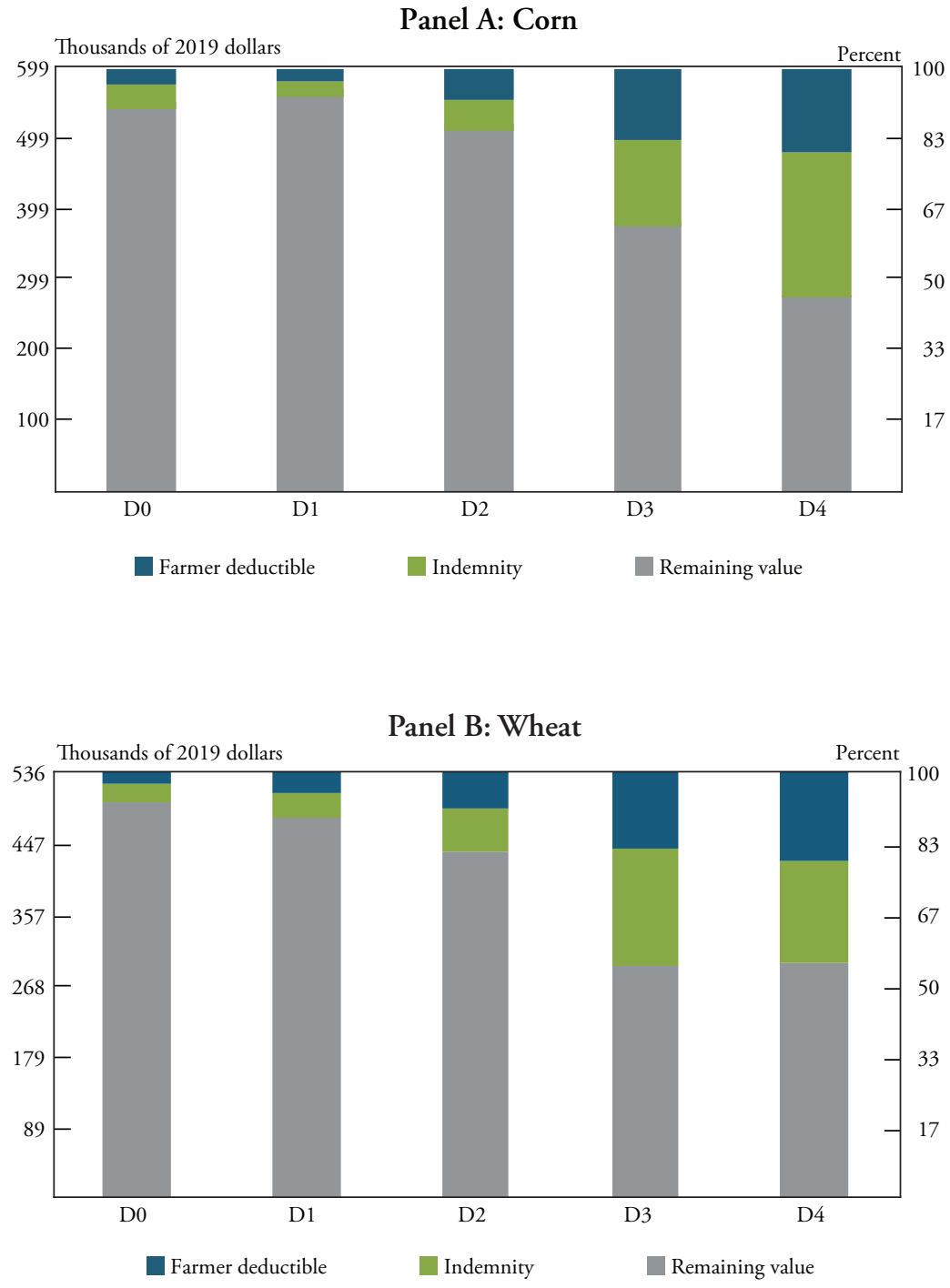


\section{Chart 5 (continued)}

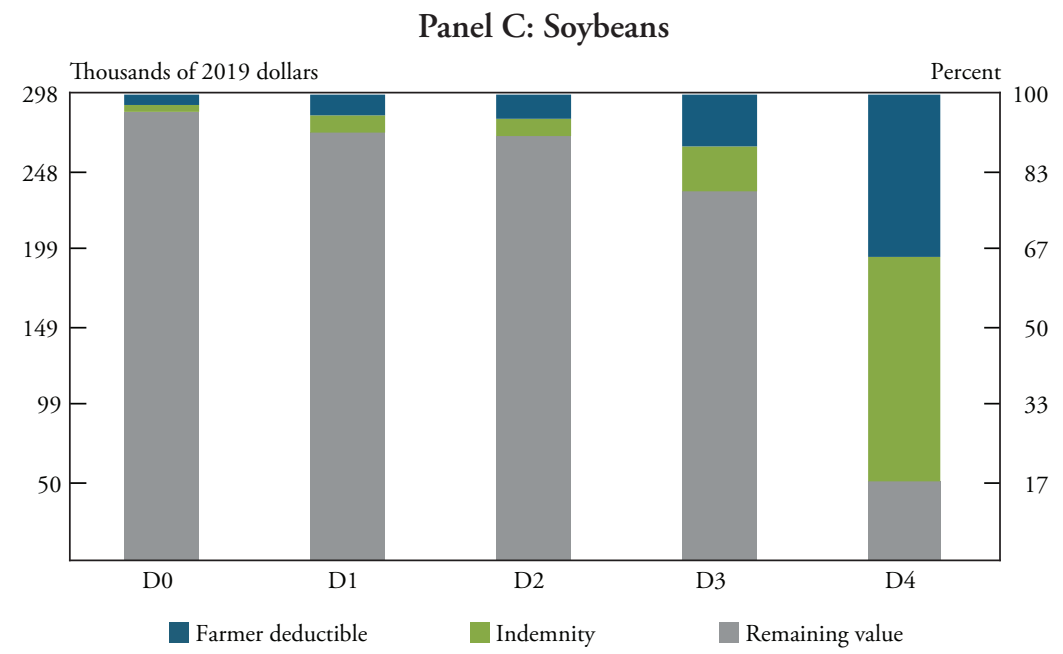

Sources: USDA, U.S. Drought Monitor, and authors' calculations.

indemnities, like farmer losses, increase drastically in more extreme drought categories, rising from just under 2 percent of production value in D0 drought to over 48 percent of value in D4 drought. Together, these indemnity data illustrate that crop insurers also face substantial losses from increasing drought severity.

If drought-related losses continue to rise, the economic effects may spill over to the broader U.S. economy. Federal crop insurance costs the U.S. government an average of $\$ 7$ billion each year through subsidies, with some of the largest losses taking place in extreme drought years. With steady growth in crop insurance market penetration over the last 20 years - and expectations that the cost of crop insurance programs will rise substantially under a changing climate- these programs could be at risk in the coming years (Glauber 2002; Crane-Droesch and others 2019). A rise in indemnity payments and crop insurance costs could result in elevated premiums for farmers (increasing their cost of production) or rising costs for the U.S. taxpayer through subsidies or transfer payments. All told, under a changing climate, the cost of managing climate risk for the U.S. agricultural sector is likely to rise in the coming decades. 


\section{Conclusion}

Drought remains a perennial threat to the U.S. agriculture sector, causing lower crop yields, higher production costs, and increased financial stress to farmers. With climate change predictions suggesting a greater incidence of drought in the coming decades, understanding how drought affects different segments of the agriculture sector is of critical importance in assessing risk from this natural hazard.

We analyze drought exposure across the United States over the last 20 years for corn, wheat, and soybeans and link these exposures to a measure of direct farmer losses (crop insurance deductibles). We find that losses for farmers rise with drought intensity and that those losses are economically relevant. We also find noticeable differences across crop types. Losses for corn and wheat rise steadily from low-intensity drought (D0) to high-intensity drought (D4), with a noticeable jump in losses from D2 to D3. In contrast, losses for soybeans rise more slowly through lower-intensity drought categories (D0-D3), with a jump in losses in the most extreme drought category (D4).

Our results suggest losses from drought are economically meaningful. Farmer losses from extreme drought can reach 20 percent of production value for corn and wheat and 35 percent for soybeans. Moreover, these losses are likely to increase in the medium term. Temperatures are expected to rise in the coming decades, with associated increases in drought frequency and severity. These changes pose risks not only to farmers but also to crop insurers, as both deductibles and indemnities will become more costly under a changing climate. Understanding the true economic cost of drought exposure may help farmers, agriculture lenders, and regulators make more informed decisions in the years to come. 


\section{Appendix A}

\section{Measuring Farmer Deductibles and Total Losses from Crop Insurance Data}

To calculate farmer loss (deductibles) and total loss at the county $(i)$, crop $(j)$, and year $(t)$ level, we aggregate up from the policy $(p)$ and insurance claim $(c)$ level using the USDA Summary of Business crop insurance policy data and USDA Cause of Loss crop insurance claims data. These data sets provide all federal crop insurance policies and policy claims within the United States for all crops. We estimate losses in a series of steps:

1) USDA Summary of Business Data (all insurance policies)

(i) Value of crop $_{i, j, t}=\sum$ liability $_{i, j, p, t} /$ coverage $_{i, j, p, t}$

We estimate the value of the crop (corn, wheat, and soybeans) within a given county by taking the liability for each crop insurance policy and dividing by the coverage level for that policy. We then sum up the crop values within a county across all crop insurance policies. This measure of crop value is used to generate county-level loss maps.

(ii) Coverage $_{i, j, t}=$ weighted-average coverage level (by acres)

We generate a weighted-average coverage level at the county, crop, and year level using policy-level coverage data. Individual coverage levels are unavailable in the Cause of Loss insurance claims data. Thus, we create a representative coverage level for a given county, crop, and year by averaging (by acres) across insurance policies within a given year. All policies labeled as catastrophic coverage (CAT) are excluded from this average coverage level calculation.

2) USDA Summary of Business Data (all insurance claims): drought only

(i) Value of crop $_{i, j, c, t}=$ liability $_{i, j, c, t} /$ coverage $_{i, j, t}$ 
We generate county-crop estimates of farmer deductibles from drought-related crop insurance claims. First we estimate crop values by taking the liability of a given claim and dividing by the representative coverage level in 1(ii). This estimate is applied for all claims that are not labeled CAT coverage. CAT coverage is paid out at 55 cents for every dollar of loss for losses exceeding 50 percent of the crop value. Thus, coverage on CAT policies is $.275(.50 \times .55)$, and we apply that coverage ratio to estimate crop values on CAT policies.

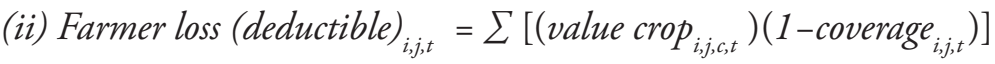
We then estimate farmer losses (deductibles) at the county, crop, and year level by taking the estimated value of the crop multiplied by the difference between the total crop value and coverage of that crop. CAT coverage claims require a slightly different calculation for the farmer deductibles. Farmer deductibles for CAT policies are estimated by the following equation: crop value $(0.50)+$ indemnity $(.45 / .55)$; as farmers are only paid 55 cents for every dollar of loss exceeding 50 percent of crop value. We then sum up farmer deductibles within a county to obtain our measure of farmer loss for a given county, crop, and year. It is this measure of loss that we use in our statistical model to link drought to farmer losses.

(iii) Total loss ${ }_{i, j, t}=$ farmer loss $(\text { deductible })_{i, j, t}+$ indemnity $_{i, j, t}$

We also generate a measure of total losses by summing the estimated farmer losses (deductibles) in 2(ii) and the total indemnities paid for drought-related claims for a given county, crop, and year. We use this measure of total loss in our drought loss maps (specifically, Map 3). This measure of loss is also used in our statistical model to demonstrate what farmer losses might be without federal crop insurance. 


\section{Appendix B}

\section{Statistical Model: Panel Regression}

We implement an ordinary least squares (OLS) panel regression framework to estimate the relationship between drought-exposed acres and farmer losses (deductibles) and total loss in real 2019 dollars. To examine the relationship between drought-exposed acres and losses, we estimate the following model for each crop (corn, wheat, and soybeans):

$$
\text { Loss }_{i, t}=\beta_{0}+\beta_{1} \text { drought }_{i, t}+\gamma_{i}+\alpha_{t}+\varepsilon_{i, t}
$$

where Loss $_{i, t}$ denotes the measure of loss (2019 dollars) for county $i$ at time $t, \gamma_{i}$ denotes county fixed effects, and $\alpha_{t}$ denotes time fixed effects. For our main specification, loss is measured as the farmer's deductible. However, we estimate a second set of specifications that estimate the relationship between drought exposures and total loss (specifically, deductibles + indemnities) for county $i$ at time $t$. Drought $t_{i, t}$ denotes the measure of drought exposure in acres. We run two specifications: annual average exposed acres (all drought categories) and average annual acres exposed by drought category (D0-D4). We use county fixed effects to control for any time-invariant characteristics that are unique to that county (such as productivity, style of farming, and location). Time fixed effects control for factors that may affect the entire agriculture sector over time (such as commodity prices, supply and demand, or trade policy).

Additionally, we run a series of unreported robustness checks including model specifications that account for irrigated acreage, periods of high and low drought severity, trimming outliers, and that use shares of exposed acres against shares of lost value. Results from these specifications are not qualitatively different than our main specification linking drought-exposed acres to losses. 
Table B-1

Model Results

Panel A: Corn

\begin{tabular}{|c|c|c|c|c|}
\hline & (1) & (2) & (3) & (4) \\
\hline Variable & $\begin{array}{c}\text { Farmer loss } \\
\text { (deductible) }\end{array}$ & Total loss & $\begin{array}{c}\text { Farmer loss } \\
\text { (deductible) }\end{array}$ & Total loss \\
\hline $\begin{array}{l}\text { Total acres in } \\
\text { drought }\end{array}$ & $\begin{array}{l}41.58^{* * *} \\
(24.97)\end{array}$ & $\begin{array}{l}90.04^{* * *} \\
(21.08)\end{array}$ & & \\
\hline Acres in D0 & & & $\begin{array}{l}25.32^{* * *} \\
(8.92)\end{array}$ & $\begin{array}{l}58.11^{* * *} \\
(7.46)\end{array}$ \\
\hline Acres in D1 & & & $\begin{array}{l}21.23^{* * *} \\
(8.38)\end{array}$ & $\begin{array}{l}42.31^{* * *} \\
(7.19)\end{array}$ \\
\hline Acres in D2 & & & $\begin{array}{l}44.97^{* * *} \\
(10.30)\end{array}$ & $\begin{array}{l}88.98^{* * *} \\
(8.73)\end{array}$ \\
\hline Acres in D3 & & & $\begin{array}{l}100.9^{* * *} \\
(10.57)\end{array}$ & $\begin{array}{c}223.6^{* * *} \\
(9.87)\end{array}$ \\
\hline Acres in D4 & & & $\begin{array}{c}118.8^{* * *} \\
(9.00)\end{array}$ & $\begin{array}{c}326.9^{* * *} \\
(8.94)\end{array}$ \\
\hline Constant & $\begin{array}{c}-784,518.2^{* * *} \\
(-15.79)\end{array}$ & $\begin{array}{c}-1,791,477.9^{* * *} \\
(-14.12)\end{array}$ & $\begin{array}{c}-546,714.8^{* * *} \\
(-12.25)\end{array}$ & $\begin{array}{c}-1,209,901.5^{* * *} \\
(-10.64)\end{array}$ \\
\hline Observations & 36,257 & 36,257 & 36,257 & 36,257 \\
\hline Adjusted $\mathrm{R}^{2}$ & 0.307 & 0.287 & .363 & .345 \\
\hline
\end{tabular}

Panel B: Wheat

\begin{tabular}{|c|c|c|c|c|}
\hline & (1) & (2) & (3) & (4) \\
\hline Variable & $\begin{array}{l}\text { Farmer loss } \\
\text { (deductible) }\end{array}$ & Total loss & $\begin{array}{l}\text { Farmer loss } \\
\text { (deductible) }\end{array}$ & Total loss \\
\hline $\begin{array}{l}\text { Total acres in } \\
\text { drought }\end{array}$ & $\begin{array}{l}19.30^{* * *} \\
(24.23)\end{array}$ & $\begin{array}{l}43.79^{* * *} \\
(22.19)\end{array}$ & & \\
\hline Acres in D0 & & & $\begin{array}{l}6.64^{* * *} \\
(4.37)\end{array}$ & $\begin{array}{l}15.82^{* * *} \\
(4.27)\end{array}$ \\
\hline Acres in D1 & & & $\begin{array}{l}11.13^{* * *} \\
(6.84)\end{array}$ & $\begin{array}{l}23.49^{* * *} \\
(6.33)\end{array}$ \\
\hline Acres in D2 & & & $\begin{array}{l}18.44^{* * *} \\
(6.47)\end{array}$ & $\begin{array}{l}39.67^{* * *} \\
(6.09)\end{array}$ \\
\hline Acres in D3 & & & $\begin{array}{l}39.47^{* * *} \\
(9.95)\end{array}$ & $\begin{array}{l}97.52^{* * *} \\
(9.53)\end{array}$ \\
\hline Acres in D4 & & & $\begin{array}{l}44.42^{* * *} \\
(11.83)\end{array}$ & $\begin{array}{l}95.95^{* * *} \\
(10.70)\end{array}$ \\
\hline Constant & $\begin{array}{c}-133,031.8^{* * *} \\
(-8.02)\end{array}$ & $\begin{array}{c}-319,218.7^{* * *} \\
(-7.98)\end{array}$ & $\begin{array}{c}-5,226.6^{* * *} \\
(-0.35)\end{array}$ & $\begin{array}{c}-26,768.2^{* * *} \\
(-0.72)\end{array}$ \\
\hline Observations & 34,385 & 34,385 & 34,385 & 34,385 \\
\hline Adjusted $\mathrm{R}^{2}$ & 0.262 & 0.243 & .393 & .373 \\
\hline
\end{tabular}


Table B-1 (continued)

Panel C: Soybeans

\begin{tabular}{|c|c|c|c|c|}
\hline & (1) & (2) & (3) & (4) \\
\hline Variable & $\begin{array}{l}\text { Farmer loss } \\
\text { (deductible) }\end{array}$ & Total loss & $\begin{array}{l}\text { Farmer loss } \\
\text { (deductible) }\end{array}$ & Total loss \\
\hline $\begin{array}{l}\text { Total acres in } \\
\text { drought }\end{array}$ & $\begin{array}{l}20.66^{* * *} \\
(25.29)\end{array}$ & $\begin{array}{l}37.30^{* * *} \\
(23.58)\end{array}$ & & \\
\hline Acres in D0 & & & $\begin{array}{l}10.26^{* * *} \\
(11.15)\end{array}$ & $\begin{array}{l}18.19^{* * *} \\
(10.76)\end{array}$ \\
\hline Acres in D1 & & & $\begin{array}{l}19.19^{* * *} \\
(12.20)\end{array}$ & $\begin{array}{l}35.30^{* * *} \\
(11.93)\end{array}$ \\
\hline Acres in D2 & & & $\begin{array}{l}24.27^{* * *} \\
(9.79)\end{array}$ & $\begin{array}{l}38.62^{* * *} \\
(8.63)\end{array}$ \\
\hline Acres in D3 & & & $\begin{array}{l}49.67^{* * *} \\
(8.84)\end{array}$ & $\begin{array}{l}93.77^{* * *} \\
(8.82)\end{array}$ \\
\hline Acres in D4 & & & $\begin{array}{c}153.4^{* * *} \\
(8.96)\end{array}$ & $\begin{array}{c}366.2^{* * *} \\
(8.99)\end{array}$ \\
\hline Constant & $\begin{array}{c}-232,319.3^{* * *} \\
(-10.25)\end{array}$ & $\begin{array}{c}-423,355.9^{* * *} \\
(-9.46)\end{array}$ & $\begin{array}{c}-207,714.7^{* * *} \\
(-8.98)\end{array}$ & $\begin{array}{c}-355,838.4^{* * *} \\
(-8.42)\end{array}$ \\
\hline Observations & 31,504 & 31,504 & 31,504 & 31,504 \\
\hline Adjusted $\mathrm{R}^{2}$ & 0.257 & 0.246 & .316 & .327 \\
\hline
\end{tabular}

* $\quad$ Significant at the 10 percent level

** Significant at the 5 percent level

*** Significant at the 1 percent level

Note: County-clustered standard errors are in parentheses.

Sources: U.S. Drought Monitor and USDA. 


\section{Endnotes}

${ }^{1}$ The climate and weather variables that make up the U.S. Drought Monitor include the Palmer Drought Index, soil moisture, streamflow percentiles, percent normal precipitation, a precipitation index, and vegetation health. The drought categories are associated with their percentile chance of occurring within a 100year period, with lowest-intensity drought D0 ("abnormally dry") having a 20-30 percent probability of occurring and D4 ("exceptional drought") having a less than 2 percent probability of occurring (Svoboda and others 2002; Kuwayama and others 2018; U.S. Drought Monitor 2020). The drought monitor further categorizes drought areas into short-term effects (less than six months) and longterm effects (greater than six months).

${ }^{2}$ Values are in CPI-adjusted 2019 dollars.

${ }^{3}$ Drought insurance claims include the following natural hazard categories: drought, heat, hot wind, and irrigation failure. Flood is the other major natural hazard faced by farmers, averaging roughly 30 percent of total crop insurance indemnities paid over the last 20 years.

${ }^{4}$ In addition to Hawaii and Alaska, we exclude Rhode Island due to its lack of drought exposure for the crops we analyze.

${ }^{5}$ Although irrigation can help some farmers mitigate drought risk during episodes of low rainfall, less than 10 percent of U.S. agriculture is irrigated, and roughly three-fourths of irrigated land is in the western United States (USDA ERS 2019). Even in areas where irrigation is possible, irrigating farmland can be expensive and may not completely offset drought risk when it is prolonged or extreme (USDA ERS 2019; Foster, Brozović, and Butler 2015). Given the relatively low share of irrigated agricultural land in the United States, our main analysis does not directly address the relationship between irrigation and drought risk. However, we do run a series of robustness checks that includes irrigated acreage. Results from these specifications are not qualitatively different than our main specification linking drought-exposed acres to losses.

${ }^{6}$ Our sample window is limited by the availability of drought data, which start in 2000 (USDM 2020). Our loss measure, while useful, may underestimate farmer losses from drought in two ways. First, our measure does not account for "shallow loss," which is when a farmer's loss is less than the deductible or coverage level. Second, our measure does not capture losses from uninsured crop production. For this reason, we focus on corn, soybeans, and wheat, which have high crop insurance market penetration.

${ }^{7}$ Appendix Table B-1 shows full results for each crop type. We provide results for both farmer deductibles and total losses (that is, indemnities + deductibles). Without crop insurance, estimated losses for farmers would roughly double. 
${ }^{8}$ The unique loss profile for soybeans may be attributable to soybeans' higher yield declines during more extreme dry periods, as soybean production is more susceptible to more extreme drought conditions (Troy, Kipgen, and Pal 2015).

${ }^{9}$ According to the USDA's Agricultural Resource Management Survey, in 2018, the size of the average U.S. business farm was 1,023 acres for corn, 675 acres for soybeans, and 2,466 acres for wheat. Average production value per acre from 2000 to 2019 in real CPI-adjusted 2019 U.S. dollars is roughly $\$ 599$ per acre for corn, $\$ 214$ per acre for wheat, and \$441 per acre for soybeans. Farmer loss estimates and indemnity estimates are taken from our model coefficient estimates in Appendix Table B-1. Indemnity estimates (per acre) are calculated as "Total loss" minus "Farmer deductible." Although we focus a majority of our discussion and analysis on farmer losses (deductibles), we show estimated indemnities and remaining value to place farmer losses in the context of broader drought losses and crop insurance payments.

${ }^{10}$ To further place farmer loss in context, consider that average net farm income from the USDA's Agricultural Resources Management Survey (2014-18) in real 2019 dollars was roughly $\$ 138,000$ for corn, $\$ 52,000$ for wheat, and $\$ 88,000$ for soybeans. Although our estimates for direct farmer loss represent a large portion of farmer income, we focus our example for the typical U.S. corn, wheat, and soybean farm on farmer losses relative to production value (revenue) rather than on income. Farm income is affected by several factors besides production, such as labor costs, seed and fertilizer expenses, fuel costs, and government payments. During a natural hazard such as drought, farmers may adjust their operations and expenses and may receive disaster payments, all of which can affect farm income separate from the shock to the farmer's production. 


\section{References}

Challinor, A. J., J. Watson, D. B. Lobell, S. M. Howden, D. Smith, and N. Chhetri. 2014. "A Meta-Analysis of Crop Yield under Climate Change and Adaptation." Nature Climate Change, vol. 4, pp. 287-291. Available at https://doi. org/10.1038/nclimate2153

Cook, Benjamin I., Richard Seager, A. Park Williams, Michael J. Puma, Sonali McDermid, Maxwell Kelley, and Larissa Nazarenko. 2019. "Climate Change Amplification of Natural Drought Variability: The Historic Mid-TwentiethCentury North American Drought in a Warmer World." Journal of Climate, vol. 32, no. 17, pp. 5417-5436. Available at https://doi.org/10.1175/JCLID-18-0832.1

Crane-Droesch, Andrew, Elizabeth Marshall, Stephanie Rosch, Anne Riddle, Joseph Cooper, and Steven Wallander. 2019. "Climate Change and Risk Management into the 21st Century." USDA Economic Research Service, report no. 266, July.

CRS (Congressional Research Service). 2018. "Federal Crop Insurance: Program Overview for the 115th Congress.” Congressional Research Service, May 10.

Donovan, Victoria M., Carissa L. Wonkka, and Dirac Twidwell. 2017. "Surging Wildfire Activity in a Grassland Biome.” Geophysical Research Letters, vol. 44, no. 12, pp. 5986-5993. Available at https://doi.org/10.1002/2017GL072901

Foster, T., N. Brozović, and A.P. Butler. 2015. "Why Well Yield Matters for Managing Agricultural Drought Risk." Weather and Climate Extremes, vol. 10, Part A, pp. 11-19. Available at https://doi.org/10.1016/j.wace.2015.07.003

FCA (Farm Credit Administration). 2017. "Crop Insurance Covers Most Major Crops.” Federal Credit Administration: Office of Regulatory Policy, September 28 .

Glauber, Joseph W., Keith J. Collins, and Peter J. Barry. 2002. "Crop Insurance, Disaster Assistance, and the Role of the Federal Government in Providing Catastrophic Risk Protection.” Agricultural Finance Review, vol. 62, no. 2, pp. 81-101. Available at https://doi.org/10.1108/00214900280001131

Gowda, Prasanna, Jean L. Steiner, Carolyn Olson, Mark Boggess, Tracey Farrigan, and Michael A. Grusak. 2018. "Agriculture and Rural Communities," in D. R. Reidmiller, C. W. Avery, D. R. Easterling, K. E. Kunkel, K. L. M. Lewis, T. K. Maycock, and B. C. Stewart, eds., Impacts, Risks, and Adaptation in the United States: Fourth National Climate Assessment, Volume II, pp. 391437. Washington, DC: U.S. Global Change Research Program. Available at https://doi.org/10.7930/NCA4.2018.CH10

Kukal, Meetpal S., and Suat Irmak. 2018. "Climate-Driven Crop Yield and Yield Variability and Climate Change Impacts on the U.S. Great Plains Agricultural Production.” Scientific Reports, vol. 8, no. 3450. Available at https://doi. org/10.1038/s41598-018-21848-2

Kuwayama, Yusuke, Alexandra Thompson, Richard Bernknopf, Benjamin Zaitchik, and Peter Vail. 2018. "Estimating the Impact of Drought on Agriculture Using the U.S. Drought Monitor." American Journal of Agricultural Economics, vol. 101, no. 1, pp. 193-210. Available at https://doi.org/10.1093/ajae/aay037 
NOAA NCEI (National Oceanic and Atmospheric Administration National Centers for Environmental Information). 2020. "U.S. Billion-Dollar Weather and Climate Disasters.” Available at https://doi.org/10.25921/stkw-7w73

Otkin, Jason A., Mark Svoboda, Eric D. Hunt, Trent W. Ford, Martha C. Anderson, Christopher Hain, and Jeffrey B. Basara. 2018. "Flash Droughts: A Review and Assessment of the Challenges Imposed by Rapid-Onset Droughts in the United States." Bulletin of the American Meteorological Society, vol. 99, no. 5, pp. 911-919. Available at https://doi.org/10.1175/BAMS-D-17-0149.1

Rippey, Bradley R. 2015. “The U.S. Drought of 2012." Weather and Climate Extremes, vol. 10, Part A, pp. 57-64. Available at https://doi.org/10.1016/j. wace.2015.10.004

Schlenker, Wolfram. 2020. "Environmental Drivers of Agricultural Productivity Growth and Socioeconomic Spillovers." Federal Reserve Bank of Kansas City 2020 Agricultural Symposium, "The Roots of Agricultural Productivity Growth."

Svoboda, Mark, Doug LeComte, Mike Hayes, Richard Heim., Karin Gleason, Jim Angel, Brad Rippey, Rich Tinker, Mike Palecki, David Stooksbury, David Miskus., and Scott Stephens. 2002. "The Drought Monitor." Bulletin of the American Meteorological Society, vol. 83, no. 8, pp. 1181-1190. Available at https://doi.org/10.1175/1520-0477-83.8.1181

Troy, T., C. Kipgen, and I. Pal. 2015. "The Impact of Climate Extremes and Irrigation on U.S. Crop Yields.” Environmental Research Letters, vol. 10, no. 5. Available at https://doi.org/10.1088/1748-9326/10/5/054013

USDA ERS (Economic Research Service). 2019. "Irrigation and Water Use." September 23.

USDA RMA (Risk Management Agency). 2020. "Insurance Plans."

U.S. Drought Monitor. 2020. "United States Drought Monitor."

Williams, A. Park, Edward R. Cook, Jason E. Smerdon, Benjamin I. Cook, John T. Abatzoglou, Kasey Bolles, Seung H. Baek, Andrew M. Badger, and Ben Livneh. 2020. "Large Contribution from Anthropogenic Warming to an Emerging North American Megadrought.” Science, vol. 368, no. 6488, pp. 314-318. Available at https://doi.org/10.1126/science.aaz960 